\title{
The relationship between treatment limitations and pressure on intensive care units in elderly patients
}

\author{
Christian Jung ${ }^{1 *} \mathbb{D}$, Hans Flaatten ${ }^{2}$, Dylan de Lange ${ }^{3}$, Michael Beil ${ }^{4}$ and Bertrand Guidet ${ }^{5}$
}

(c) 2021 The Author(s)

\section{Dear Editor,}

The pandemic caused by SARS-CoV-2 coronavirus disease 2019 (COVID-19) disproportionally affected the elderly population especially in the initial phase. During the different surges of the pandemic, some intensive care units (ICUs) were overwhelmed by a huge influx of patients. Criteria were discussed for patient admission as well as for possible limitation of care. This had to be done despite an increase in bed capacity to avoid exhaustion of resources. Evidence-based thresholds for ICU patientto-caregiver ratios [1], above which patient safety may be endangered, were not realistic to provide during the COVID-19 pandemic in many countries.

Criteria about resource allocation should ensure fairness, enhance consistency, and decrease moral distress in providers [2]. It has been heavily debated whether chronological age or age cut-offs can serve as criterion to guide therapy decisions. For example, Dutch ethicists even developed triage guidelines for when patients cannot be discerned based on medical differences. Whom should then be admitted to the last ICU bed? Younger generation could be prioritized over older generation in that horrible scenario. This could be considered to be discriminatory and the question whether age in itself should be considered acceptable as a selection criterion remains unsolved. What is considered ethically acceptable or not differs between societies as is illustrated by the huge differences in, for example, end-of-life care or withholding

\footnotetext{
*Correspondence: christian.jung@med.uni-duesseldorf.de ${ }^{1}$ Department of Cardiology, Pulmonary Diseases and Vascular Medicine, Faculty of Medicine, Düsseldorf University Hospital, Moorenstraße 5, 40225 Düsseldorf, Germany

Full author information is available at the end of the article
}

of treatments while being admitted to the ICU [3]. Our analysis sought to investigate the relationship between the decision to limit therapy and the 7-day incidence of COVID-19 patients as a surrogate of ICU pressure in elderly patients.

The Corona Virus disease in Very Elderly Intensive care Patients (COVIP study) was a multinational, prospective, observational study in elderly ICU patients. This analysis included 2984 patients from 35 countries. The 7-day incidence was retrieved from the World Health Organization (WHO) database [4] and matched with the individual patients' date of symptom onset in the respective country. Further characteristics recorded and the definition of treatment limitation such as withholding or withdrawal were described previously [5]. Data were analyzed using the hexagon heat map illustration tool and logistic regression analysis in STATA (IC 16.1, TX, USA).

Figure 1 shows the relationship between limitation of care, the 7-day incidence, and age. A shift in the frequency of treatment limitations can be found toward also younger ages with increasing incidences. In multivariable logistic regression, the odds for treatment limitation were independently associated with age [adjusted odds ratio (aOR): 1.07 per year (confidence interval 1.06-1.09, $p<0.001]$ and 7 -day incidence (aOR 1.12 per $100 / 100.000$ (confidence interval 1.06-1.18, $p<0.001$ ) adjusting for sex, frailty, and disease severity (Sequential Organ Failure Assessment Score).

One limitation of our analysis is that we do not have a specific measure of ICU burden, which ideally should take into account staffing, other patients, and emotional burden, among other factors.

In summary, 7-day incidence is likely to play a role in critical-care decision-making in older patients, especially

\section{Springer}




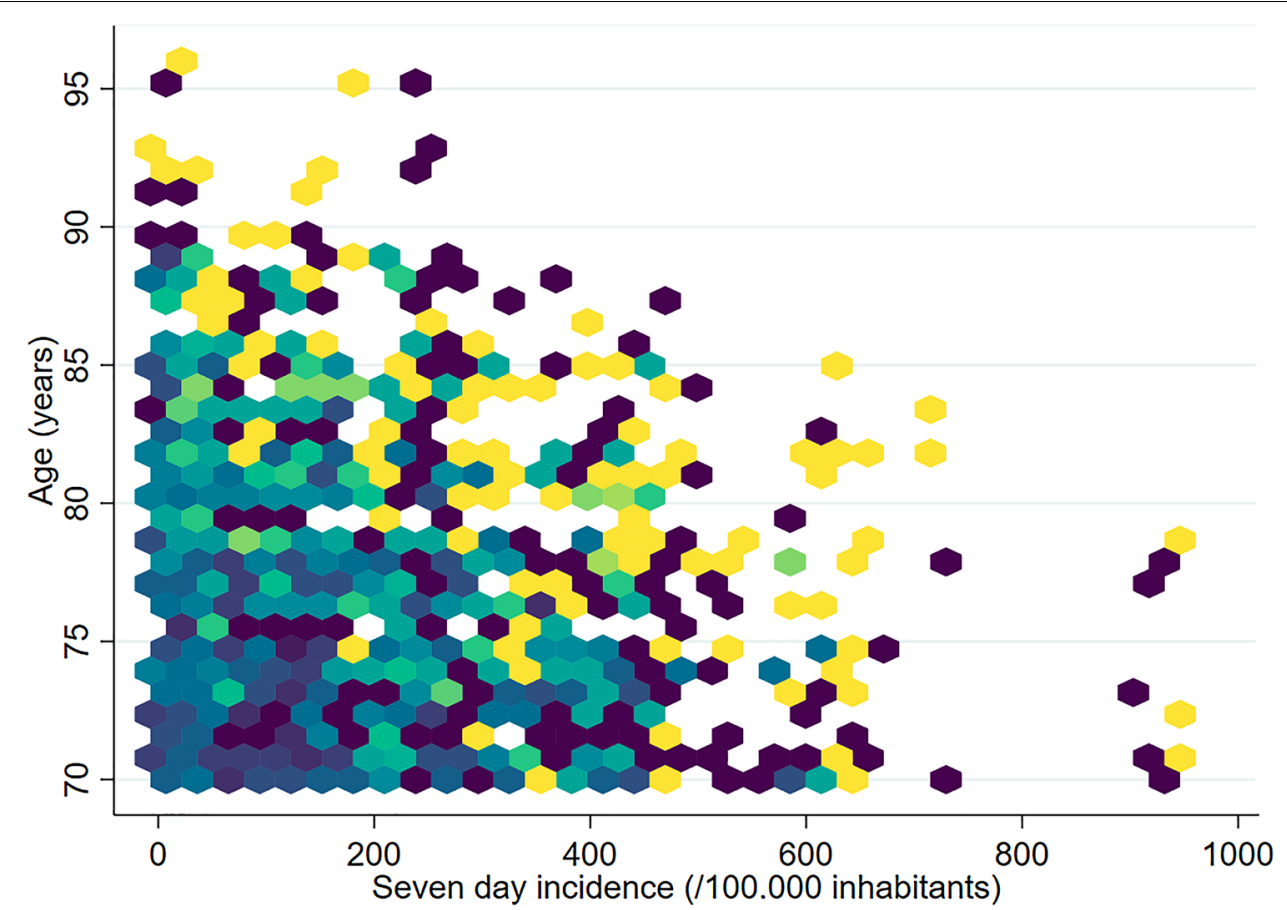

Fig. 1 A 20-step color gradient illustrates the density of the occurrence of the event (withholding or withdrawal of treatment) in relation to age and 7-day incidence. Yellow codes the highest event density; dark blue the lowest

when the health system is under pressure from many admissions.

\section{Author details}

1 Department of Cardiology, Pulmonary Diseases and Vascular Medicine, Faculty of Medicine, Düsseldorf University Hospital, Moorenstraße 5, 40225 Düsseldorf, Germany. ${ }^{2}$ Department of Anaesthesia and Intensive Care, Haukeland University Hospital, Bergen, Norway. ${ }^{3}$ Department of Intensive Care Medicine, University Medical Center, University Utrecht, Utrecht, The Netherlands. ${ }^{4}$ Department of Medicine, NHS Scotland, Inverness, UK. ${ }^{5}$ Service de Réanimation Médicale, Assistance Publique-Hôpitaux de Paris, Hôpital Saint-Antoine, Paris, France.

\section{Funding}

Open Access funding enabled and organized by Projekt DEAL.

\section{Declarations}

\section{Conflicts of interest}

The authors declare that they have no competing interests.

\section{Open Access}

This article is licensed under a Creative Commons Attribution-NonCommercial 4.0 International License, which permits any non-commercial use, sharing, adaptation, distribution and reproduction in any medium or format, as long as you give appropriate credit to the original author(s) and the source, provide a link to the Creative Commons licence, and indicate if changes were made. The images or other third party material in this article are included in the article's Creative Commons licence, unless indicated otherwise in a credit line to the material. If material is not included in the article's Creative Commons licence and your intended use is not permitted by statutory regulation or exceeds the permitted use, you will need to obtain permission directly from the copyright holder. To view a copy of this licence, visit http://creativecommons.org/licen ses/by-nc/4.0/.

\section{Publisher's Note}

Springer Nature remains neutral with regard to jurisdictional claims in published maps and institutional affiliations.

Accepted: 7 October 2021

Published online: 5 November 2021

\section{References}

1. Neuraz A, Guerin C, Payet C, Polazzi S, Aubrun F, Dailler F, Lehot J, Piriou V, Neidecker J, Rimmele T, Schott AM, Duclos A (2015) Patient mortality is associated with staff resources and workload in the ICU: a multicenter observational study. Crit Care Med 43:1587-1594

2. Sprung CL, Joynt GM, Christian MD, Truog RD, Rello J, Nates JL (2020) Adult ICU triage during the coronavirus disease 2019 pandemic: who will live and who will die? Recommendations to improve survival. Crit Care Med 48:1196-1202

3. Avidan A, Sprung CL, Schefold JC, Ricou B, Hartog CS, Nates JL, Jaschinski U, Lobo SM, Joynt GM, Lesieur O, Weiss M, Antonelli M, Bulow HH, Bocci MG, Robertsen A, Anstey MH, Estebanez-Montiel B, Lautrette A, Gruber A, Estella A, Mullick S, Sreedharan R, Michalsen A, Feldman C, Tisljar K, Posch M, Ovu S, Tamowicz B, Demoule A, DeKeyser GF, Pargger H, Noto A, Metnitz P, Zubek L, de la Guardia V, Danbury CM, Szucs O, Protti A, Filipe M, Simpson SQ, Green C, Giannini AM, Soliman IW, Piras C, Caser EB, Hache-Marliere M, Mentzelopoulos SD, Group E-S (2021) Variations in end-of-life practices in intensive care units worldwide (Ethicus-2): a prospective observational study. Lancet Respir Med 9:1101-1110

4. https://covid19.who.int/. Last accessed 07 Sep 2021

5. Jung C, Flaatten H, Fjolner J, Bruno RR, Wernly B, Artigas A, Bollen Pinto B, Schefold JC, Wolff G, Kelm M, Beil M, Sviri S, van Heerden PV, Szczeklik W, Czuczwar M, Elhadi M, Joannidis M, Oeyen S, Zafeiridis T, Marsh B, Andersen FH, Moreno R, Cecconi M, Leaver S, Boumendil A, De Lange DW, Guidet B, Group CS (2021) The impact of frailty on survival in elderly intensive care patients with COVID-19: the COVIP study. Crit Care 25:149 